\title{
THE IMPACT OF KNOWLEDGE MANAGEMENT ON WAGE GROWTH IN THE CONSTRUCTION SECTOR: THE CASE OF MEDIUM-SIZED AND LARGE COMPANIES IN THE REPUBLIC OF SERBIA
}

\author{
Vojislav Babici* and Sinisa Zaric ${ }^{2}$ \\ ${ }^{1}$ Institute for Sociological Research, Faculty of Philosophy, University of Belgrade \\ ${ }^{2}$ Faculty of Economics, University of Belgrade
}

The study measures and analyzes the influence of knowledge management on average wages in Serbian construction companies. For the purpose of this research, of Knowledge Management (KM) dataset with 11 variables was created. The main goal of the research was to examine the influence of the dataset on the average wages in medium-sized and large construction companies. At the basic sample level, through factor analysis, a total of four factor scores were isolated, representing the strategies that the companies combine in KM. Using a regression analysis, it was found that the set of the four independent variables explained $84.5 \%$ of the average wage variability in the medium-sized and large construction companies. Two of the four strategies were statistically significant. According to the first strategy, the management insisted on a larger share of experts with the master's and bachelor degrees, while the second strategy was based on the introduction of the formal, legal protection and registration of innovative solutions, as well as a larger number of employees with a PhD degree.

Keywords: knowledge management, construction sector, factor analysis, multiple regression, wages, midsize and large companies

JEL Classification: M21, M150

\section{INTRODUCTION}

Information and knowledge are important resources and drivers in the era of the 4.0 Industrial Revolution (Xu, David \& Kim, 2018). Therefore, there is a growing

* Correspondence to: V. Babic, Institute for Sociological Research, Faculty of Philosophy, 18 Cika Ljubina street, Belgrade, The Republic of Serbia;

e-mail: babic.voja@gmail.com interest in the knowledge management discipline. It is a discipline focused on the management and allocation of knowledge and information, with the aim of increasing the efficiency and value of a company. The aim of the paper is to prove the impact of Knowledge Management (KM) on the business variables of Serbian mid-sized and large construction companies. From the group of business 
variables, the earnings of employees were extracted. For the majority of employees, wages are the most important source of income for paying a rent, food and bills, and for paying off loans. Higher-wage employees can afford a more expensive lifestyle (Hartman, 2017). Higher wages are not only a form of rewards, but also a way to earn loyalty. Increasing wages raises employee's morale and productivity. In addition, employees' consumer power grows. Higher employee consumption stimulates production, retail and the service sector. Higher employees' wages have a positive impact on job creation and government revenue through taxes, providing more funding for new projects and services. The construction sector was selected due to its specificity, dynamism and connection with other industries. In economic sciences, the construction sector is considered to have a significant impact on the economic development of one country (Dang \& Sui Pheng, 2015).

This paper starts from the basic hypothesis:

$\mathrm{H}$ : KM positively affects the average wage growth in medium-sized and large construction companies in the Republic of Serbia.

As a measuring instrument, a KM dataset containing 11 variables classified into five thematic units: academic education, employee training, storage, dissemination and technical support was created. An online closed-ended-response questionnaire with the interval and Likert scales was used to collect the data from the managers of a total of 130 companies. For the purposes of this study, the average wages of the companies' employees were measured. Creating a tool for measuring the level of the wages in companies was a two-stage process. In the pilot survey, the respondents were first asked to directly answer the question: What is the average wage in your company? As no answer was received due to the fact that the question about the wages was direct and of a delicate and sensitive nature, the respondents were offered an interval scale to determine their wages, which did not produce results, either. Therefore, in the second stage, a special wage scale with three numerical degrees was created so as to indirectly obtain the data on the average wage in the Republic. The respondents were asked: Is the average wage in your company lower than, equal to or higher than the national average for the Republic of Serbia (RS)? The data for the average wages in RS for the year 2017 were taken from the Službeni glasnik (7/2018). The impact of $\mathrm{KM}$ on employees' wages was measured by using appropriate statistical and econometric techniques.

The chapter entitled The Construction Sector as an Impetus for Economic Growth discusses the specificities of the construction sector and analyzes its impact on the economic development of mature and developing economies. The chapter entitled The Application of Knowledge Management in the Construction Sector defines the concept of KM and highlights its functions in economic sciences and management. Besides, the application of KM in the construction sector is analyzed by using various case studies. In the chapter entitled Empirical Research some of the results obtained from the empirical research on the impact of KM on employees' wages in Serbian companies will be presented.

\section{THE CONSTRUCTION SECTOR AS AN IMPETUS FOR ECONOMIC GROWTH}

Due to its dynamism and connection with other industries, the construction sector has a significant impact on the economic development of one country. The development of and an increase in turnover in the construction sector trigger a flywheel, which may lead to a range of economic benefits. In the first place, there is an increase in employment (Mallick \& Mahalik, 2010; Stanišić, 2017) due to the induced impact on other business sectors. The development of the construction sector leads to an increase in demand for goods and services necessary for the construction of buildings, bridges, road and railway infrastructures, etc. This has a positive impact on the development of the mechanical and manufacturing industries, trade, services, transport and the financial sector, as construction projects may take a long time and require a continuous inflow of significant funds. 
In a study L. Ruddock and J. Lopes (2006) confirmed the positive impact of gross value added as an indicator of the activity in the construction sector on the GDP per capita growth in developed and developing countries. Using the Granger causality test and time series regression analysis for the period from 1950 to 2005, a fact was pointed out that there was a connection between the construction sector and the real GDP growth rate in Pakistan (Khan, 2008). Based on the results, a higher flow in the construction sector precedes the GDP growth, while causality in the opposite direction was not found. Pakistan's aggregate economy was found to be heavily influenced by the construction sector. Based on an input-output analysis, A. Wibowo, F. X. Sugiyanto, M. Firmansyah and O. Amoudi (2008) demonstrated the importance of the construction industry for Indonesia's economy. According to the authors, the construction industry significantly contributes to local and national economies, as it has the capacity to generate unskilled, semi-skilled and skilled labor. The construction industry requires the input mobilization from other industries, as well as from production factors, which may lead to a significant increase in the employment rate due to the multiplier effect. Analyzing the role of the construction sector in Turkmenistan's economic development, the authors point out the fact that the construction industry makes a significant contribution to the output and employment in developed and developing countries (Durduyev \& Ismail, 2012). Since 2011, considerable funds have been earmarked in Turkmenistan for investment in the reconstruction of the country. The Government of Turkmenistan has provided a range of subsidized housing loans, which has accelerated the development of the construction industry. In addition, a large number of companies have been privatized, which has had a positive impact on competitiveness, productivity and growth in all branches of industry, including construction. However, the authors point out the fact that there is only one construction faculty in the country. As a result, there is a lack of knowledge and skilled workforce in Turkmenistan. Therefore, the authors believe that more educational institutions should be founded in all areas of the construction industry.
Analyzing the impact of the business cycles in the construction sector on the economies of the USA, the UK and South Korea, J. Park, T. Ham and T. Hong (2012) point out the fact that, in many countries, the construction sector is crucial for development, typically accounting for $5-10 \%$ of the GDP. The authors point out the fact that construction is closely connected with the financial market. This is evidenced by the developments in the USA mortgage crisis in 2007 that greatly shook the construction sector. In a study on the impact of the construction industry on the economy of Rhode Island, a federal state of the USA (Tebaldi, 2014), the author points out the fact that this industry is important for direct job creation and income in the country, as well as strong connections with other industries, the retail, health and social protection sectors, manufacturing, the food and beverage industry, tourism, the real estate sector and leasing services. Based on Tebaldi's estimates, \$10 million in the construction output support 146 direct and induced jobs in the state. Every 100 jobs created in the construction industry support 83 jobs in other sectors through the induced economic activity. According to A. Deutsche (2019), the USA construction industry is in a growing phase. Employment in the construction sector is predicted to increase by $11 \%$ in the period from 2016 to 2026, leading to the creation of 750,000 new jobs. Employment growth in this sector is a product of overall economic growth and the population growth, which has led to an increase in demand for housing, roads and other structures.

Regarding the efficiency of the Serbian construction sector, the research study has shown that a systematic approach to the implementation of the measures that would change the institutional environment produces much better results than state intervention and direct financial incentives (Mladenovic, 2013). According to macroeconomic trends report Narodna Banka Srbije $(2019,10)$, as a result of the adoption of the Law on Planning and Construction and the Law on Investments, there was an increase in the number of issued building permits and an increase in the sector's share in the GDP in 2015-2019 period. 


\section{THE APPLICATION OF KNOWLEDGE MANAGEMENT IN THE CONSTRUCTION SECTOR}

Obtaining growth in the construction sector is a particular challenge. Achieving business success in this sector by inertia leads to growth and development in other economic sectors. Therefore, the construction sector is an interesting area for the introduction of creative business management strategies. One of those strategies is $\mathrm{KM}$, which may positively impact business variables in construction companies. $\mathrm{KM}$ is particularly interesting in the 4.0 Industrial revolution era, when knowledge and information are the key resource(s) for a faster innovation cycle and economic prosperity (Wisniewska-Salek, 2019). From the aspect of economic sciences, $\mathrm{KM}$ is the process of acquiring and allocating knowledge resources in order to achieve greater business efficiency and companies' profitability. The beginnings of the creation of the scientific concept of KM date back to the 1990s (Nonaka, 1991; Drucker, 1993; Davenport, 1994). According to Webster's financial and investment vocabulary, KM is the process of creating, institutionalizing and distributing knowledge for the purpose of improving and organizing business processes and practices (Webster, 2010). Explaining the notion of KM, Rose states that it is a concept in which a company consciously and comprehensively collects, organizes, shares and analyzes its knowledge in terms of resources, documents and human skills (Rouse, 2013). KM refers to the technologies involved in the creation, dissemination and use of knowledge data (Girard \& Girard, 2015).

In the 21st century, $\mathrm{KM}$ is applied in the construction sector, as evidenced by a large number of scientific studies. A case study (Forcada, Casals, Roca \& Gngolells, 2006) describes the strategy of introducing KM into a Spanish construction company, Natur System, specialized in facade restoration and recovery. ICT platforms with software adapted for the creative storage of knowledge and the procedures related to the functioning of small and mediumsized construction companies were used as the main instrument for strategy implementation. At the request of Natur System Company, the software was adapted in order to filter information in the following segments: quality, the environment, the safety and health aspect, progress, changes, contracts, pricing, projects, risk and programming. The main objective was to increase the efficiency of the company and improve its cooperation with clients and relevant companies. After the testing on the main façade restoration project at 359 Balmes Street in Barcelona had been completed, the authors concluded that the introduction of the conceptual ideas of KM brought benefits to the overall management of construction companies. Improvements in documentation management and cooperation among the employees within the company were noticed, the exchange of useful information with clients and other companies was improved. However, the transaction costs related to the problem of the employees' adoption of and adaptation to new technologies were reported (Forcada et al, 2006).

According to C. Leal, S. Cuhna and I. Cuoto (2017) the construction sector is going through a period of instability and recession, which is one of the causes for the insufficient adaptation to the knowledge era. The authors would like to highlight the inhibitory and suitability factors of knowledge sharing in the construction sector (Table 1).

The authors conclude that the collaboration of researchers in the IT field may contribute to overcoming inhibitions for knowledge sharing in the construction sector. The development of a more creative piece of software for the acquisition and sharing of knowledge will encourage and motivate employees in the construction sector to share knowledge not only as a duty, but also as a desire. H. Robinson, P. Carrillo, C. Anumba and M. AlGhassani (2001) conducted a research on the results of the implementation of $\mathrm{KM}$ in large construction companies in the United Kingdom. The research study covered a total of 170 companies with a turnover greater than $£ 50$ million (Robinson et al, 2001). Large companies were selected because they had the biggest need for the introduction of $\mathrm{KM}$ and because of the assumption that they had the greatest financial and human resources to implement this 
type of innovation. According to the authors, small organizations are also keen to adopt the concept of $\mathrm{KM}$, but they are faced with a lack of skill resources in employees, as well as financial constraints. Based on the results, the authors conclude that a large number of construction companies are aware of the benefits of KM. However, companies face barriers to the implementation of concepts such as a lack of money, a poor IT infrastructure, organizational culture, and time constraints.

Table 1 The individual, organizational, inhibitory and facilitating factors of knowledge sharing in the construction sector

\begin{tabular}{|c|c|c|}
\hline & Individual factors & Organizational factors \\
\hline Facilitators & $\begin{array}{l}\text { - Conformity to } \\
\text { corporate culture } \\
\text { - Reciprocity } \\
\text { - Perceived value } \\
\text { and the uniqueness } \\
\text { of knowledge } \\
\text { - Peer recognition } \\
\text { - Honoring } \\
\text { knowledge sharing } \\
\text { commitments } \\
\text { - Mimicking leaders' } \\
\text { behavior }\end{array}$ & $\begin{array}{l}\text { - Financial/social } \\
\text { motivations } \\
\text { - Culture }\end{array}$ \\
\hline Inhibitors & - & $\begin{array}{l}\text { - Resources - mainly } \\
\text { time } \\
\text { - Mainly the male } \\
\text { sector } \\
\text { - High turnover } \\
\text { - Low level of training/ } \\
\text { intellectual capital } \\
\text { - Culture }\end{array}$ \\
\hline
\end{tabular}

Source: Leal et al, 2017

A. Javernick-Will (2012) examined the reasons for employees' sharing knowledge in the USA construction and real estate companies. In a qualitative case study, conducted on a sample of 48 employees in 13 companies, the author identified the four major factors that influence knowledge sharing and the perception of organizational knowledge value: resources, intrinsic motivation, global incentives and social motivation. The vast majority of the respondents cited social motivation, reciprocity, alignment with corporate culture, the imitation of leaders, the awareness of the importance of sharing knowledge and information with colleagues, respect for the obligation to share knowledge, and the perception of organizational knowledge values as the reasons for motivation for knowledge sharing. A. JavernickWill (2012) also outlines the strategies that may help employees increase knowledge sharing across companies. The author notes certain disadvantages of the application of the qualitative method in this field. She states that future research should increase the sample size and use quantitative methods with a standard questionnaire. This would measure the ranking of the importance that the respondents attach to the motivational factors revealed in the research study. Increasing the sample would also allow comparative research with the European companies that cultivate different business patterns. According to S. Asad, M. Khalfan and P. McDermott (2005), the application of KM in the construction sector leads to improvements in processes and products (due to knowledge exchange in the supply chain), saving money (due to the centralization of communication among business partners) or an increase in earnings, as a result of using centralized knowledge as a source of competitive advantage for building new and retaining old. The construction industry faces low productivity, which Grover and Froese see as a reason for scarce KM (Grover \& Froese, 2016). The authors noted that the mistakes made in one construction project are repeated in future construction projects. The main objective of their research was to evaluate the usefulness of social platforms for the management of tacit knowledge in the construction industry. An analysis of the implementation of social platforms in the construction industry was conducted in a case study of the Vancouver AYO Smart Home company at a time when demand for low-cost, durable and energy-efficient housing was growing in Canada. Social platforms use applications to facilitate communication and collaboration between different project stakeholders. According to the authors, using an application should enable the participation of two or more individuals in the creative process, 
the exchange of collective skills, expertise, a better understanding of information, all in a business atmosphere of openness and mutual respect.

\section{EMPIRICAL RESEARCH}

\section{Sample and Dataset Design}

The sample includes companies from Belgrade, Novi Sad and Niš, as the largest business centers in Serbia. The sample covers the following five economic sectors: industrial, construction, IT, commercial and services. When planning the sample, due care was taken that the share of the economic sectors in Serbia's GDP was credibly maintained in the sample (Republički zavod za statistiku, 2018). In the selection of companies, due care was taken to maintain a realistic ratio in the sample when the number of micro-, small, mediumsized and large companies in Serbia is concerned. The criteria from the applicable Law on Accounting (Vlada Republike Srbije, 2013) were used to define the company size. The sampled companies were selected from the list of the Business Directory of Serbia (Stojanovic, 2018) by using the simple random sample method without repetition. An online closedended-response questionnaire with the interval and Likert scales was used to collect the data. The managers of the selected companies were included in the survey. The interview was being conducted from November 1 to December 15, 2018. The questionnaire was distributed three times at 15-day intervals. The second and third times, the questionnaires were sent again to the companies that had not submitted their answers after the first and second attempts. Out of the 360 questionnaires sent, the responses were received from 130 companies, representing the basic sample. Table 2 shows the number of the companies by size and sectors.

The so-called segmented sample, which includes a total of the 12 medium-sized and large construction companies extracted from the basic sample, was also used in the subject-matter analysis.
Table 2 The number of the companies by size and business sectors

\begin{tabular}{|c|c|c|c|c|c|}
\hline \multirow{2}{*}{$\begin{array}{l}\text { Business } \\
\text { sector }\end{array}$} & \multicolumn{4}{|c|}{ Company size } & \multirow{2}{*}{ Total } \\
\hline & Micro & Small & Medium & Large & \\
\hline Industry & 4 & 9 & 10 & 8 & 31 \\
\hline $\begin{array}{l}\text { Constru- } \\
\text { ction }\end{array}$ & 8 & 10 & 7 & 5 & 30 \\
\hline IT sector & 7 & 8 & 2 & 3 & 20 \\
\hline Commerce & 6 & 7 & 5 & 3 & 21 \\
\hline Services & 6 & 13 & 4 & 5 & 28 \\
\hline Total & 31 & 47 & 28 & 24 & 130 \\
\hline
\end{tabular}

Source: Authors

For the research purposes, a dataset for measuring $\mathrm{KM}$ in the companies was created. The dataset consists of the 11 variables classified into the five thematic units: the first unit, called academic education, includes the following three variables: the proportion of the employees in the company with a bachelor, master's and PhD degrees; the second unit, called employee training, involves the following variables: attending seminars and courses outside the company, as well as educational seminars and courses inside the company; the third thematic unit, called storage, consists of the following variables: the presence of an organized procedure for storing necessary knowledge useful for the functioning of the company and the existence of a system for the protection and registration of innovative solutions and procedures in the Intellectual Property Office; the fourth unit, called dissemination, contains the following two variables: the existence of an obligation for participants in innovative knowledge seminars to report on the results to their respective departments, sectors or immediate colleagues, as well as the variable that measures the existence of the employees' obligation to inform their colleagues about the results concerning the activity of the company upon returning from a business trip (after visiting fairs, 
exhibitions and other business events); ultimately, the fifth unit, called technical support, includes two variables: the first variable evaluates a possibility of accessing the intranet in companies, and the second measures a possibility of accessing virtual libraries and knowledge bases. The variables were measured by using the interval and four-point Likert scales, where 1 is the minimum, and 4 is the maximum value of the measured indicator. The survey also includes the measurement of the companies' business variables.

\section{Model, Analysis and Results}

A total of 11 variables from the KM measurement dataset were processed by the factor analysis technique at the basic-sample level including all the five sectors $(n=130)$. The initial idea was to isolate a number of the complex factors that would later be linked to the companies' business variables. The analysis started with the following basic model:

$$
X_{i}=a_{i 1} F_{1}+a_{i 2} F_{2}+a_{i 3} F_{3}+a_{i 4} F_{4}+e_{i}
$$

where $X$ is the value of the factor score, $i$ is the sequence number of the variable, $F$ represents the factors, $a$ is the factor loadings, and $e$ is the specific factor related only to the given variable.

A factor analysis using the maximum likelihood extraction method was used in the study (Millar, 2011). The extraction algorithm in the maximum likelihood variant (Field, 2005) is so set that the maximum likelihood of the options $\Lambda$ and $\psi 2$ is obtained by minimizing Equation 2:

$$
F=\operatorname{tr}\left[\left(\Lambda \Lambda^{\prime}+\psi 2\right)-1 R\right]-\log \left|\left(\Lambda \Lambda^{\prime}+\psi 2\right)-1 R\right|-p
$$

and according to $\Lambda$ and $\psi 2$, respectively, where $p$ represents the number of the variables, $\Lambda$ is the factor loading matrix, and $\psi 2$ is the diagonal matrix of the unique variance.

$F$ is minimized through a two-step logarithm. In the first step, the conditional minimum for $F_{i}$ calculated for the given $y$. In this way, the function $f(\psi)$ is obtained and numerically minimized by the Newton-Raphson method (Field, 2005; Ahmad, Naing \& Hussein, 2007).
As all the necessary conditions of Kaizer-Mayer and Bartlett's test for continuing the analysis were met (Field, 2005), the factor analysis procedure started. Following the varimax rotation, the four significant complex factors were identified. The factor loadings are shown in Table 3. Cumulatively observed, the four factors explain $50 \%$ of the total variance. Generally, the minimum value of the factor loadings considered in studies is \pm 0.3 , while the factor loadings with values \pm 0.70 are considered as indicative for the well-defined structure and they are a true target of the factor analysis (Hair, Black, Babin \& Anderson, 2010). Accordingly, all the cells with significant factor loadings in Table 3 are colored gray.

At the basic-sample level, the four factors that represent the strategies that the companies used and combined in KM were extracted. Factor 1 includes the strategy that relies on attending educational seminars inside and outside the company, the obligation to report to departments, sectors or their immediate colleagues on the results of innovative knowledge seminars, subscription fees for accessing virtual libraries and knowledge bases, and organizing knowledge storage procedures useful for the functioning of the company. Finally, as part of this strategy, the companies strive to have as many professionals with a college degree as possible among the employees. Factor 2 contains the strategy that includes an obligation for employees to inform their colleagues about their business performance results upon returning from business trips, the obligation to report to their respective departments, sectors or immediate colleagues on the results of innovative knowledge seminars and knowledge storage procedures useful for functioning of the company. Within Factor 3, KM relies on the strategy that seeks to maximize the percentage of professionals with a master's and bachelor degrees among the employees. Factor 4 implies the strategy that emphasizes the existence of the system of formal legal protection and registration of innovative solutions and procedures in appropriate institutions, as well as the largest possible number of employed experts holding a $\mathrm{PhD}$ degree. The company's management may use one 
Table 3 The rotated factor matrix $\mathrm{n}=130$

\begin{tabular}{|c|c|c|c|c|}
\hline & \multicolumn{4}{|c|}{ Factor } \\
\hline & 1 & 2 & 3 & 4 \\
\hline The number of the employees with a bachelor degree, in $\%$ & .308 & .053 & .460 & .125 \\
\hline The number of those with an MSc/MA degree, in \% & .055 & .064 & .826 & -.021 \\
\hline The number of PhDs & .120 & -.019 & .207 & .430 \\
\hline Attending seminars and courses outside the company, in \% & .544 & .091 & .086 & .124 \\
\hline Attending educational seminars and courses inside the company, in \% & .948 & .046 & .208 & .078 \\
\hline $\begin{array}{l}\text { Are there organized procedures for storing necessary knowledge useful } \\
\text { for the functioning of the company? }\end{array}$ & .388 & .332 & .191 & .106 \\
\hline $\begin{array}{l}\text { Is there a system of protection and registration of innovative solutions } \\
\text { and procedures (in the Intellectual Property Office)? }\end{array}$ & .159 & .047 & -.119 & .798 \\
\hline $\begin{array}{l}\text { Do participants in innovative knowledge seminars have the obligation } \\
\text { to report the results to their respective departments and sectors, or } \\
\text { immediate colleagues? }\end{array}$ & .486 & .370 & -.070 & .216 \\
\hline $\begin{array}{l}\text { Upon returning from business trips (after visiting fairs, exhibitions and } \\
\text { other business events), are employees obliged to inform their coworkers } \\
\text { about the results concerning the company's activities? }\end{array}$ & .168 & .969 & .070 & -.164 \\
\hline Is there access to virtual libraries and knowledge bases? & .575 & .155 & .097 & .132 \\
\hline Are you connected via the intranet? & .067 & .218 & .024 & .178 \\
\hline
\end{tabular}

Extraction Method: Maximum Likelihood. Rotation Method: Varimax with Kaiser Normalization.

a. Rotation converged into 5 iterations.

Source: Authors

KM strategy or combine multiple KM strategies as well. The choice of strategies depends on the business sector, the company size, the business environment and other circumstances.

Using the obtained four-factor score, it is possible to measure the impact of KM strategies on a company's business variables. The study measured the impact of the factor scores on the 'wages' business variable. The employees' wages were measured over the wage scale consisting of three numerical degrees. In the survey, the following question was used: Is the average wage in your company lower than, equal to or higher than the national average for The Republic of Serbia? The impact of the four-factor scores on the wages in the medium-sized and large construction companies was analyzed. The operational hypothesis H1 was tested: The regression factor scores 1 - 4 (as the independent variables, the predictors) influence the change in the dependent variable called the wages of the employees in the company' in medium-sized and large construction companies. In order to test the hypothesis, a segmentation of the basic sample was performed, extracting a total of 12 medium-sized and large construction companies. After the segmentation, the following multiple regression model was set:

$$
w_{i}=\beta_{0}+\beta_{1} f i_{1}+\beta_{2} f i_{2}+\beta_{3} f i_{3}+\beta_{4} f i_{4}+\varepsilon_{i}
$$

where, for $i=n$ observations:

$w i=$ the dependent variable (the company's average wage)

$\beta 0=w$ intercept (the constant)

$\beta_{1}=$ the slope coefficient of the predictor $f_{i 1}$ 
$\beta_{2}=$ the slope coefficient of the predictor $f_{i 2}$

$\beta_{3}=$ the slope coefficient of the predictor $f_{i 3}$

$\beta_{4}=$ the slope coefficient of the predictor $f_{i 4}$

$f_{i 1^{\prime}} f_{i 2^{\prime}} f_{i 3^{3}} f_{i 4}=$ the independent variables or predictors (the regression factor scores 1 - 4)

$\varepsilon_{i}=$ the random error

The results show significant values for all the three $\mathrm{R}$ coefficients (Table 4). Due to the limitations of the smaller sample, the adjusted coefficient $\mathrm{R}^{2}$, which has more severe criteria, is used in the analysis. Based on the value of the adjusted $\mathrm{R}^{2}$, the set of the four predictor variables explains $84.5 \%$ of the variability of the employees average wages.

Table 4 The medium-sized and large construction companies: the regression analysis model summary

\begin{tabular}{ccccc}
\hline Model & $\mathrm{R}$ & $\mathrm{R}^{2}$ & Adjusted $\mathrm{R}^{2}$ & $\begin{array}{c}\text { Std. error } \\
\text { of the } \\
\text { estimate }\end{array}$ \\
\hline 1 & $.949 a$ & .901 & .845 & .153 \\
\hline
\end{tabular}

a. Predictors: (Constant), REGR. factor score 4 for Analysis 1, REGR. factor score 2 for Analysis 1, REGR. factor score 1 for Analysis 1, REGR factor score 3 for Analysis 1

Source: Authors

Table 5 shows the contributions by factor scores. Factors 3 and 4 have a statistically significant effect on the employees' average wages. Accordingly, construction company management use a combination of the two KM strategies.

The first strategy involving the efforts of the management to have as high a percentage of professionals with master's and bachelor degrees as possible among the employees. Management sees in experts the sources of innovative solutions useful for the company.
Table 5 The medium-sized and large construction companies: Coefficientsa

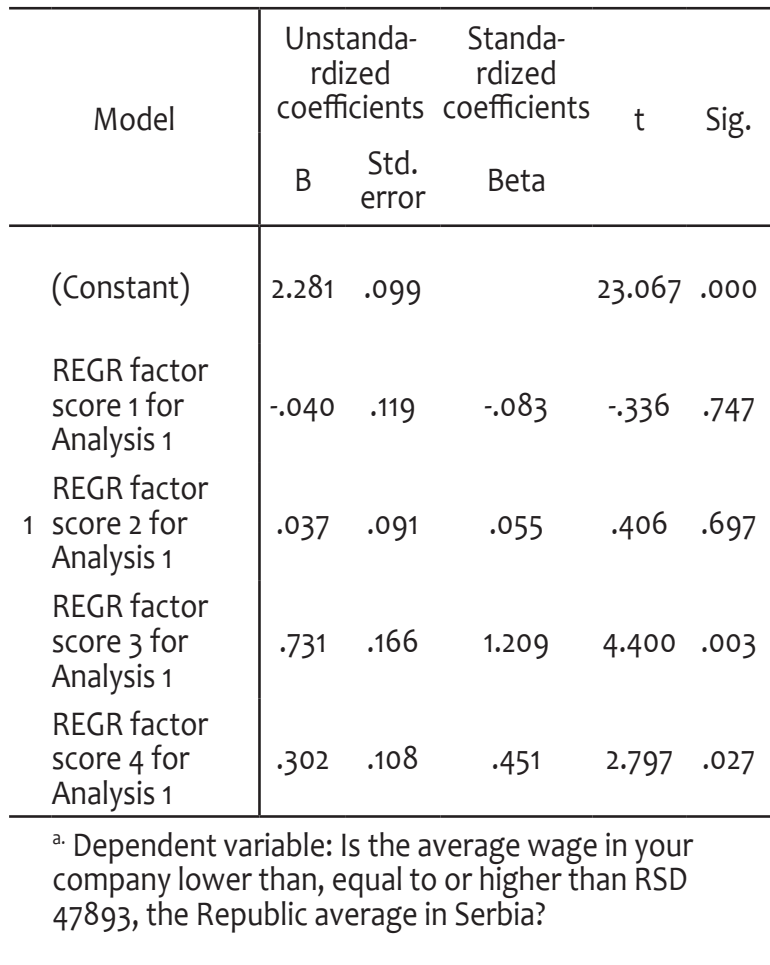

Source: Authors

The second strategy implies the introduction of the formal legal protection and registration of innovative solutions and procedures in the Intellectual Property Office, as well as insisting on a larger number of employees with PhDs. Given the value of the coefficient $\beta_{1^{\prime}}$ the first strategy individually leads to a larger increase in the average wages in the company. When the factor score 3 jumps by one point, employees' wages increase by 0.731 . If the factor score 4 goes up by one point, wages jump by 0.302 . It can be concluded that the hypothesis $\mathrm{H} 1$ has been confirmed. No segmentation and differentiation in the context of the medium-sized or large companies in particular was possible since, in this case, the sample size fell below the statistically acceptable limit. 


\section{CONCLUSION}

In this study, the impact of KM on wages growth in medium-sized and large construction companies in Serbia was analyzed. For the purposes of the research study, a KM dataset consisting of 11 variables was created. After a factor analysis, the strategies applied in KM were identified. Then, the impact of the regression factor scores on the change in the dependent variable called average wages in medium-sized and large construction companies was analyzed. Based on the obtained value of the adjusted coefficient of determination $\mathrm{R} 2$, the regression factor scores were found to explain $84.5 \%$ of the variability of the average wages of the company's employees', thus confirming the hypothesis H1. Construction companies management combine two statistically significant strategies for KM. In the first strategy, management strive to have as many employees with a master's and bachelor degrees as possible among their employees, seeing them as a potential source for company innovation. The second strategy involves the implementation of the legal protection and registration of the company's innovative solutions and procedures in the Intellectual Property Office, as well as the efforts to recruit more employees with PhDs. When the regression factor score 3, which refers to the first strategy, increases by one point, employees' wages increase by 0.731 . When the factor score 4 , pertaining to the second strategy, increases by one point, wages in construction companies jump by 0.302 . Speaking about the sample, certain limitations related to the small, segmented sample may be observed. However, based on the insight into a very clear trend in the responses received, it is believed that a larger sample would not influence change in the results.

P. Romer (Brueck, 2018) emphasized the importance of the impact of endogenous knowledge accumulation for increasing income. P. Romer pointed out the fact that, instead of repeating the same movements over and over again, working hard in factories or on computers, people could rearrange the world and discover new ideas through knowledge accumulation. In the idea market, there is a snowball effect. As Romer says: „The more we know, the easier it gets to discover".
The implications of the research results are primarily related to the orientation towards the company internal market. The notion of an internal market implies that the managerial and ownership structures see employees as the consumers of "products", among which wages and money stimulants, hierarchical positions, trainings, etc. are the most important. Given the fact that the number of these "internal products" is limited, the importance of wages, which provides an opportunity for a gradual approach compared to the demonstrated knowledge and contributions, remains paramount. For this reason, according to the research results presented in this paper, $\mathrm{KM}$ in a segmented internal market produces significant implications for company results.

\section{REFERENCES}

Ahmad, W., Naing, N., \& Hussein, M. (2007). Selection for parameter $\Lambda$ by using newton-raphson method. Statistika, 7(2), 33-37. Retrieved July 25, 2019 from https://ejournal. unisba.ac.id/index.php/statistika/article/download/987/582

Asad, S., Khalfan, M., \& McDermott, P. (2005, April). Managing knowledge across the construction supply Chain. Paper presented at SCRI Symposium in Salford, UK, 12 -13 April, Retrieved July 20, 2019 from https://www.irbnet.de/daten/ iconda/CIB16777.pdf 20/07/2019

Brueck, H. (2018). Economist Paul Romer just won the Nobel Prize in economics-and his ideas sound like the backbone of Bill Gates' philanthropy playbook. Business Insider (Oct. 8th), Retrieved July 26, 2019 from https://www.businessinsider. com/paul-romer-nobel-prize-in-economics-endogenousgrowth-theory-2018-10

Dang, G., \& Sui Pheng, L. (2015). Infrastructure Investments in Developing Economies: The Case of Vietnam. Singapore: Springer

Davenport, T. H. (1994). Saving IT's Soul: Human Centered Information Management. Harvard Business Review, 72(2), 119-131.

Deutsch, A. (2019). The 5 Industries Driving the U.S Economy. Retrieved July 20, 2019, from https://www.investopedia. com/articles/investing/042915/5-industries-driving-useconomy.asp 
Drucker, P. F. (1993). Managing in Turbulent Times. London, UK: Routledge.

Durduyev, S., \& Ismail, S. (2012). Role of the Construction industry in economic development of Turkmenistan. Energy Education Science and Technology Part A: Energy Science and Research, 29(2), 883-890.

Field, A. P. (2005). Discovering statistics using SPSS. London, UK: Sage.

Forcada, N., Casals, M., Roca, X., \& Gngolells, M. (2006, January). Knowledge management in the construction sector: A case study. Paper presented at CIB W107 Construction in Developing Countries International Symposium Construction in Developing Economies: New Issues and Challenges 18-20 January 2006, Santiago, Chile. Retrieved July 18, 2019, from http://www.irbnet.de/daten/iconda/ CIB1921.pdf

Girard, J., \& Girard, J. (2015). Defining knowledge management: Toward an applied compendium. Online Journal of Applied Knowledge Management, 3(1), 1-20.

Grover, R., \& Froese, T. (2016). Knowledge management in construction using a SocioBIM platform: A case study of AYO smart home project. Procedia Engineering, 145, 12831290. doi.org/10.1016/j.proeng.2016.04.165

Hair, J., Black, W., Babin, B., \& Anderson, R. (2010). Multivariate Data Analysis - A Global Perspective. New Jersey, NJ: Pearson Education.

Hartman, D. (2017). Importance of wages. Bizfluent portal. Retrieved July 21, 2019, from https://bizfluent.com/info8228392-importance-wages.html

Javernick-Will, A. (2012). Motivating knowledge sharing in engineering and construction organizations: Power of social motivations. Journal of Managemen in Engineering, 28(2), 193-202. doi:10.1061/(ASCE)ME.1943-5479.0000076

Khan, R. (2008, August). Role of construction sector in economic growth: Empirical evidence from Pakistan economy. Paper presented at First International Conference on Construction In Developing Countries (ICCIDC-I)"Advancing and Integrating Construction Education, Research \& Practice", August 4-5, 2008, Karachi, Pakistan.

Leal, C., Cuhna, S., \& Cuoto. I. (2017). Knowledge sharing in construction sector-faciliators and inhibitors. Procedia Computer Science 121, 998-1005. doi.org/10.1016/j. procs.2017.11.129
Mallick, H., \& Mahalik, M. (2010). Constructing the economy: The role of construction sector in India's growth. Journal of Real Estate Finance and Economics, 40(3), 368-384. doi:10.1007/ s11146-008-9137-z

Millar, R. B. (2011). Maximum Likelihood Estimation and Inference: With Examples in R, SAS and ADMB. New York, NY: John Wiley and Sons.

Mladenovic, I. (2013). The Construction industry in function of the recovery of the Republic of Serbia economy. Economic horizons 15(3), 249-259. doi:10.5937/ekonhor1303245M

Narodna Banka Srbije. (2019). Makroekonomska kretanja u Srbiji (Jul). Preuzeto 26. jula 2019. sa https://www.nbs.rs/internet/ latinica/18/18_3/prezentacija_invest.pdf

Nonaka, I. (1991). The knowledge-creating company. Harvard Business Review, 69(6), 96-104.

Park, J., Ham, T., \& Hong, T. (2012). Construction Business cycle analysis using the regime switching model. Journal of Management in Engineering, 28(4), 362-371. doi:10.1061/ (ASCE)ME.1943-5479.0000107

Republički zavod za statistiku. (2018). Bruto domaći proizvod 2017. Preuzeto 25.oktobra 2019. sa https://www.stat.gov.rs/ sr-latn/vesti/20181001-bruto-doma\%C4\%87i-proizvod-2017/

Robinson, H., Carrillo, P., Anumba, C., \& Al-Ghassani, M. (2001, September). Perceptions and Barriers in Implementing Knowledge Management Strategies in Large Construction Organizations. Proceedings of the RICS Foundation Construction and Building Research Conference, 3-5 Sept. Volume 2 (p. 451460). Glasgow, UK: Glasgow Caledonian University.

Rouse, M. (2013). Knowledge Management(KM). SearchDomino websait. Retrieved July 14, 2019, from https://searchdomino. techtarget.com/definition/knowledge-management

Ruddock, L., \& Lopes, J. (2006). The construction sector and economic development: The 'Bon curve'. Construction Management and Economics, 24(7), 717-723. doi:10.1080/01446190500435218

Službeni glasnik. (2018). Prosečne zarade po zaposlenom u RS. Službeni glasnik RS 7/2018.

Stojanovic, G. (2018). Serbian Business Directory. Beograd, RS: TELCOM. 
Stanišić, N. (2017). Makroekonomske koristi od unapređenja energetske efikasnosti u stambenim zgradama u Srbiji. Bonn/ Eschborn: Deutsche Gesellschaft für Internationale Zusammenarbeit (GIZ) GmbH

Tebaldi, E. (2014). The Economic Impact of the Construction Industry on the Economy of Rhode Island in 2013. Smithfield, Rhode Island: Bryant University, Center for Global and Regional Economic Studies.

Vlada Republike Srbije. (2013). Zakon o računovodstvu. Službeni glasnik RS, 62/2013, 4-5.

Webster. (2010). Webster's New World Finance and Investment Dictionary. Indianapolis, Ind: Wiley Publishing, Inc.
Wibowo, A., Sugiyanto, F. X., Firmansyah, M., \& Amoudi, O. (2008, November). The effects of the Indonesian construction industry on the economy: A series of inputoutput table analysis. Proceedings of CIB W055 - W065 Joint International Symposium, 15-18 Nov. Heriot-Watt University, School of the Built Environment, UK. Retrieved July 19, 2019, from http://www.irbnet.de/daten/iconda/CIB17549. pdf

Wisniewska-Salek, A. (2019). Knowledge management Education in the light of Industry 4.0. CzOTO, 1(1), 969-977. doi.org/10.2478/czto-2019-0123

Xu, M., David, J., \& Kim, S. (2018). The fourth industrial revolution: Opportunities and challenges. International Journal of Financial Research, 9(2), 90-95. doi:10.5430/ijfr. v9n2p90

\author{
Received on $3^{\text {rd }}$ December 2019, \\ after revision, \\ accepted for publication on $13^{\text {th }}$ April 2020 \\ Published online on $24^{\text {th }}$ April 2020
}

Vojislav Babic is a researcher at the Institute for Sociological Research, Faculty of Philosophy, University of Belgrade. He obtained PhD at the Faculty of Economics, University of Belgrade. He is currently at the Ca' Foscari University of Venice for scientific development. His research interests are: entrepreneurship, institutional economics, and economic statistics.

Sinisa Zaric is a full professor at the Faculty of Economics, University of Belgrade, where he also gained his $\mathrm{PhD}$. Key areas of his scientific interest are: economic analyses methods, and institutional economics. 


\title{
UTICAJ MENADŽMENTA ZNANJA NA RAST ZARADA U GRAĐEVINSKOM SEKTORU: SLUČAJ SREDNJIH I VELIKIH KOMPANIJA U REPUBLICI SRBIJI
}

\author{
Vojislav Babić ${ }^{1 *}$ i Siniša Zarić $^{2}$ \\ ${ }^{1}$ Institut za sociološka istraživanja, Filozofski fakultet, Univerzitet u Beogradu \\ ${ }^{2}$ Ekonomski fakultet Univerziteta u Beogradu
}

\begin{abstract}
U studiji se meri i analizira uticaj menadžmenta znanja na prosečne zarade u građevinskim kompanijama u Republici Srbiji. Za potrebe istraživanja, kreirana je baza podataka za merenje menadžmenta znanja, sastavljena od 11 varijabli. Glavni cilj u istraživanju bio je da se ispita uticaj baze podataka na prosečne zarade zaposlenih u srednjim i velikim građevinskim kompanijama. Na nivou osnovnog uzorka, putem faktorske analize izolovana su četiri faktorska skora - strategije koje se kombinuju u menadžmentu znanja. Pomoću regresione analize, utvrđeno je da set od četiri nezavisne varijable objašnjava $84,5 \%$ varijabilnosti prosečne zarade zaposlenih u srednjim i velikim građevinskim kompanijama. Pri tome su statistički signifikantne dve strategije. U prvoj, menadžment insistira na većem udelu stručnjaka sa master i fakultetskim diplomama u zaposlenima, dok se druga strategija zasniva na uvođenju formalnopravne zaštite i registracije inovativnih rešenja kao i na većem broju zaposlenih doktora nauka.
\end{abstract}

Ključne reči: menadžment znanja, građevinski sektor, faktorska analiza, višestruka regresija, zarade, srednje i velike kompanije

JEL Classification: M21, M150

\section{UVOD}

Informacije i znanje predstavljaju važne resurse i pokretače $\mathrm{u}$ doba Četvrte industrijske revolucije $(\mathrm{Xu}$, David \& Kim, 2018). Zbog toga, raste interesovanje za disciplinu menadžment znanja. To je disciplina koja se fokusira na upravljanje i alokaciju znanja sa

* Korespondencija: V. Babić, Institut za sociološka istraživanja, Filozofski fakultet, Univerzitet u Beogradu, Čika Ljubina 18-20, Beograd, Republika Srbija; e-mail: babic.voja@gmail.com ciljem povećanja efikasnosti i vrednosti kompanije. Cilj rada je da se dokaže uticaj menadžmenta znanja na poslovne varijable srednjih i velikih građevinskih firmi u Republici Srbiji (RS). Iz grupe poslovnih varijabli, izdvojene su zarade zaposlenih. Zarade za većinu zaposlenih predstavljaju najvažniji izvor prihoda za plaćanje stanarine, hrane, računa i otplatu kredita. Zaposleni sa većim zaradama mogu sebi da priušte skuplji životni stil (Hartman, 2017). Veće zarade predstavljaju vid nagrade, ali i način za sticanje lojalnosti. Povećanje zarade podiže radni 
moral i produktivnost zaposlenih. Pored toga, raste potrošačka moć zaposlenih. Većom potrošnjom zaposlenih stimuliše se proizvodnja, maloprodaja i sektor usluga. Veće zarade zaposlenih pozitivno utiču na kreiranje novih radnih mesta i na prihode vlade kroz poreze, čime se obezbeđuje više sredstava za nove projekte i usluge. Sektor građevinarstva izabran je zbog svoje specifičnosti, dinamičnosti i povezanosti sa drugim industrijama. U ekonomskoj nauci smatra se da građevinski sektor ima značajan uticaj na ekonomski razvoj jedne zemlje (Dang \& Sui Pheng, 2015).

U ovom radu polazi se od sledeće hipoteze:

$\mathrm{H}$ : Menadžment znanja pozitivno utiče na rast prosečnih zarada u srednjim i velikim građevinskim kompanijama u Republici Srbiji.

Kao instrument, kreirana je baza podataka za merenje nivoa menadžmenta znanja. Baza sadrži jedanaest varijabli, razvrstanih u pet tematskih jedinica: akademsko obrazovanje, obuka zaposlenih, skladištenje, deljenje znanja i tehnička podrška. Za prikupljanje podataka od menadžera 130 kompanija korišćeni su online upitnik sa zatvorenim odgovorima, intervalske i Likertove lestvice. Kreiranje alata za merenje nivoa zarada u kompanijama predstavljao je dvostepeni proces. U pilot istraživanju, respondentima je traženo da direktno odgovore na pitanje - kolika je prosečna zarada u vašoj kompaniji? Pošto nije dobijen odgovor, zbog direktnog, delikatnog i osetljivog pitanja o zaradama, respondentima je ponuđena intervalska skala za utvrđivanje njihove zarade, što, takođe, nije dalo rezultat. Stoga je u drugoj fazi kreirana posebna skala za merenje zarada, sa tri numerička stepena, kako bi se indirektno dobili podaci o prosečnoj republičkoj zaradi. Respondentima su postavljena pitanja: da li je prosečna zarada u vašoj kompaniji manja, jednaka, ili veća od republičkog proseka za RS? Podaci o prosečnim zaradama u RS, za 2017, preuzeti su iz Službenog glasnika (7/2018). Uticaj menadžmenta znanja na zarade zaposlenih meren je korišćenjem odgovarajućih statističkih i ekonometrijskih tehnika. U istraživanju su korišćeni statistički metod i odgovarajuće ekonometrijske tehnike.
Pored Uvoda i Zaključka, rad je strukturiran $\mathrm{u}$ tri celine. U drugom delu rada, razmatraju se specifičnosti građevinskog sektora i analizira njegov uticaj na ekonomski razvoj zrelih ekonomija i zemalja $u$ razvoju. Nakon toga, $u$ trećem delu, definiše se koncept menadžmenta znanja i ukazuje na njegove funkcije. Pored toga, primena menadžmenta znanja $\mathrm{u}$ građevinskom sektoru analizira se na primeru različitih studija slučaja. U delu rada u kojem je sprovedeno empirijsko istraživanje, predstavljeni su neki od rezultata koji ukazuju na uticaj menadžmenta znanja na zarade zaposlenih u kompanijama u RS.

\section{GRAĐEVINSKI SEKTOR KAO POKRETAČ EKONOMSKOG RASTA}

Zbog svoje dinamičnosti i povezanosti sa ostalim privrednim granama, građevinski sektor ima značajan uticaj na ekonomski razvoj zemlje. Razvoj i povećanje obrta u građevinskom sektoru predstavlja pokretač koji može da dovede do čitavog niza ekonomskih benefita. U prvom redu, dolazi do povećanja zaposlenosti (Mallick \& Mahalik, 2010; Stanišić, 2017), zbog indukovanog uticaja na ostale poslovne sektore. Razvoj građevinskog sektora dovodi do povećanja potražnje robe i usluga neophodnih za izgradnju zgrada, mostova, putne i železničke infrastrukture i dr. To pozitivno utiče na razvoj mašinske i prerađivačke industrije, trgovine, uslužnog sektora, saobraćaja, ali i finansijskog sektora, jer građevinski projekti mogu da traju dugo, pa iziskuju kontinuelni priliv značajnih sredstava.

U istraživanju, L. Les Rudok i J. J. Lopes (2006) su potvrdili pozitivan uticaj bruto dodate vrednosti, kao indikatora aktivnosti u građevinskom sektoru, na rast BDP per capita $\mathrm{u}$ razvijenim i zemljama $\mathrm{u}$ razvoju. Korišćenjem Grejndžerovog (Granger) testa kauzalnosti i regresione analize vremenskih serija, za period 1950-2005, ukazano je na postojanje veze građevinskog sektora i realne stope rasta BDP $u$ Pakistanu (Khan, 2008). Na osnovu rezultata, veći uspeh u građevinskom sektoru prethodi rastu BDP, dok $\mathrm{u}$ obrnutom smeru kauzalitet nije utvrđen. Ustanovljeno je da je agregatna ekonomija Pakistana 
u velikoj meri pod uticajem građevinskog sektora. A. Wibowo, F. X. Sugiyanto, M. Firmansyah i O. Amoudi (2008), na osnovu input-output analize, demonstrirali su značaj građevinske industrije na ekonomiju Indonezije. Prema navedenim autorima, građevinska industrija značajno doprinosi lokalnoj i nacionalnoj ekonomiji, jer ima sposobnost da generiše nekvalifikovanu, polukvalifikovanu i kvalifikovanu radnu snagu. Građevinska industrija zahteva mobilisanje inputa kako iz ostalih industrija, tako i iz proizvodnih faktora. To može da dovede do značajnog povećanja stope zaposlenosti usled multiplikatorskog efekta. Analizirajući ulogu građevinskog sektora u ekonomskom razvoju Turkmenistana, S. Durduyev i S. Ismail (2012) ističu da građevinska industrija ima značajan doprinos na output i zaposlenost $\mathrm{u}$ razvijenim $\mathrm{i}$ zemljama $\mathrm{u}$ razvoju). Od 2011, u Turkmenistanu se izdvajaju značajna sredstva za investiranje u rekonstrukciju zemlje. Vlada Turkmenistana omogućila je čitav niz subvencionisanih stambenih kredita, što je pospešilo razvoj građevinske industrije. Pored toga, veliki broj firmi je privatizovan što je uticalo pozitivno na konkurentnost, produktivnost i rast u svim granama industrije, pa i u građevinskoj. Međutim, autori ukazuju da u zemlji postoji samo jedan građevinski fakultet. Usled toga je u Turkmenistanu prisutan nedostatak znanja i obučenosti radne snage. Stoga, smatraju autori, potrebno je da se oformi veći broj obrazovnih institucija u svim oblastima građevinske industrije.

Analizirajući uticaj poslovnih ciklusa u građevinskom sektoru na ekonomiju Sjedinjenih Američkih Država (SAD), Ujedinjenog Kraljevstva (UK) i Južne Koreje, J. Park, T. Ham i T. Hong (2012) ističu da je u velikom broju zemalja građevinski sektor ključan za razvoj i da obično pravi 5-10\% BDP. Ovi autori ističu da je građevinarstvo usko povezano sa finansijskim tržištem. O tome svedoče i dešavanja vezana za hipotekarnu krizu u SAD 2007, koja su, u velikoj meri, uzdrmala građevinski sektor. U studiji o uticaju građevinske industrije na ekonomiju Rod Ajlenda, savezne države SAD (Tebaldi, 2014), ističe se da ova industrija ima značaj za direktno kreiranje radnih mesta i prihoda u državi kao i jake veze sa drugim industrijama, maloprodajom, sektorom zdravstvene i socijalne zaštite, proizvodnjom, prehrambenom i industrijom pića, turizmom, sektorom nekretnina kao i sa uslugama lizinga. Na osnovu procena E. Tebaldi-ja (2014), deset miliona dolara građevinskog outputa podrži 146 direktnih i indukovanih poslova u državi. Svakih 100 poslova nastalih u građevinskoj industriji, podrži 83 posla u drugim sektorima, preko indukovane ekonomske aktivnosti. Prema A. Deutsch-u (2019), građevinska industrija SAD se nalazi u fazi rasta. Predviđa se da će, u periodu 20162026 , zaposlenost u građevinskom sektoru porasti za $11 \%$, što će dovesti do nastanka 750.000 novih radnih mesta. Rast zaposlenosti u ovom sektoru je proizvod ukupnog ekonomskog rasta, ali i porasta broja stanovnika, što je dovelo do povećanja potražnje za stanovima, putevima i ostalim strukturama.

Kada je reč o efikasnosti građevinskog sektora $\mathrm{u}$ $\mathrm{RS}$, istraživanja su pokazala da sistemski pristup u primeni mera za promenu institucionalnog ambijenta daje mnogo bolje rezultate od državne intervencije i direktnih finansijskih podsticaja (Mladenovic, 2013). Prema izveštaju Narodne banke Srbije (NBS) o makroekonomskim kretanjima (2019, 10), kao posledica usvajanja Zakona o planiranju i izgradnji i Zakona o ulaganjima, u periodu 2015-2019, došlo je do povećanja broja izdatih građevinskih dozvola i rasta udela ovog sektora u BDP.

\section{PRIMENA MENADŽMENTA ZNANJA U GRAĐEVINSKOM SEKTORU}

Ostvarivanje rasta u građevinskom sektoru predstavlja poseban izazov. Postizanje poslovnih uspeha u ovom sektoru po inerciji dovodi do rasta $\mathrm{i}$ razvoja u drugim privrednim sektorima. Zbog toga, građevinski sektor predstavlja interesantnu oblast za uvođenje inovativnih strategija poslovnog upravljanja. Jedna od takvih strategija jeste i menadžment znanja, koji može pozitivno da utiče na poslovne varijable $\mathrm{u}$ građevinskim kompanijama. Menadžment znanja je posebno interesantan u vremenu Četvrte industrijske revolucije, kada znanje i informacije predstavljaju ključan resurs za brži inovativni ciklus i ekonomski prosperitet (Wisniewska-Salek, 2019). U ekonomskoj 
nauci opšteprihvaćen je stav da je menadžment znanja proces usvajanja, alokacije i primene resursa znanja, sa ciljem postizanja veće poslovne efikasnosti i profitabilnosti kompanija. Počeci kreiranja naučnog koncepta menadžmeta znanja vezuju se za 90-te godine XX-og veka (Nonaka, 1991; Drucker, 1993; Davenport, 1994). Prema finansijskom i investicionom rečniku, menadžment znanja je proces kreiranja, institucionalizovanja i distribucije znanja u svrhu poboljšanja i organizovanja poslovnih procesa i prakse (Webster, 2010). Objašnjavajući pojam menadžmenta znanja, M. Rouse (2013) navodi da je to koncept u kome firma svesno i sveobuhvatno sakuplja, organizuje, deli i analizira svoje znanje $u$ smislu resursa, dokumenata i ljudskih veština. Menadžment znanja se odnosi na tehnologije uključene $u$ kreiranje, širenje i korišćenje podataka o znanju (Girard \& Girard, 2015).

U XXI-om veku, menadžment znanja se primenjuje u građevinskom sektoru, o čemu svedoči veliki broj naučnih studija. U studiji slučaja (Forcada, Casals, Roca \& Gngolells, 2006), opisuje se strategija uvođenja menadžmenta znanja u špansku građevinsku kompaniju Natur System, specijalizovanu za restauraciju i oporavak fasada. Kao glavni instrument za uvođenje strategije korišćene su platforme informaciono komunikacionih tehnologija (ICT), sa software-om prilagođenim za kreativno skladištenje znanja i procedura vezanih za funkcionisanje malih i srednjih građevinskih firmi. Na zahtev kompanije Natur System, software je adaptiran da filtrira informacije $u$ sledećim segmentima: kvalitet, okolina, sigurnost i zdravstveni aspekt, napredak, promene, ugovori, cene, projekti, rizik i programiranje. Glavni cilj bio je da se poveća efikasnost kompanije i da se unapredi saradnja sa klijentima i relevantnim firmama. Posle završenog testiranja na projektu restauracije glavne fasade u ulici Balmes 359 u Barseloni, autori zaključuju da uvođenje konceptualnih ideja menadžmenta znanja donosi benefite celokupnom menadžmentu građevinskih kompanija. Zapažena su poboljšanja u upravljanju dokumentacijom, u saradnji zaposlenih unutar kompanije, unapređena je razmena korisnih informacija sa klijentima i drugim kompanijama. Ipak, registrovani su transakcioni troškovi koji se vezuju za problem usvajanja i prilagođavanja zaposlenih na nove tehnologije (Forcada et al, 2006). C. Leal, S. Cuhna i I. Cuoto (2017) ukazuju da se građevinski sektor nalazi u vremenu nestabilnosti i recesije, što predstavlja jedan od uzroka nedovoljnog prilagođavanja na eru znanja. Ovi autori žele da istaknu inhibitorske i faktore pogodnosti za razmenu znanja u građevinskom sektoru (Tabela 1).

Tabela 1 Individualni, organizacioni, inhibicijski i olakšavajući faktori deljenja znanja u građevinskom sektoru

\begin{tabular}{|c|c|c|}
\hline & Individualni faktori & Organizacioni faktori \\
\hline Fasilitatori & $\begin{array}{l}\text { - Prilagođenost } \\
\text { kulturi organizacije } \\
\text { - Reciprocitet } \\
\text { - Percepirana } \\
\text { vrednost i } \\
\text { jedinstvenost } \\
\text { znanja } \\
\text { - Percepcija vršnjaka } \\
\text { - Poštovanje } \\
\text { obaveze deljenja } \\
\text { znanja } \\
\text { - Oponašanje lidera } \\
\end{array}$ & $\begin{array}{l}\text { - Finansijske/socijalne } \\
\text { motivacije } \\
\text { - Kultura }\end{array}$ \\
\hline Inhibitori & - & $\begin{array}{l}\text { - Resursi - uglavnom } \\
\text { vreme } \\
\text { - Uglavnom muški } \\
\text { sektor } \\
\text { - Veliki obrt } \\
\text { - Nizak nivo obuke/ } \\
\text { intelektualnog } \\
\text { kapitala } \\
\text { - Kultura }\end{array}$ \\
\hline
\end{tabular}

Izvor: Leal et al, 2017

Zaključak C. Leal-a et al (2017) jeste da u prevazilaženju inhibicija za deljenje znanja u građevinskom sektoru, može da doprinese saradnja istraživača na polju informacionih tehnologija (IT). Razvoj kreativnijih software-a za prikupljanje i deljenje znanja, ohrabriće i motivisati zaposlene $\mathrm{u}$ građevinskom sektoru da razmena znanja ne bude samo dužnost, već da postane i želja. H. Robinson, P. Carrillo, C. Anumba i M. AlGhassani (2001) sproveli su istraživanje o rezultatima implementacije menadžmenta znanja u velikim 
građevinskim kompanijama u UK. Obuhvaćeno je 170 kompanija, sa obrtom od preko 50 miliona funti. Velike kompanije su odabrane zato što imaju najveću potrebu za uvođenje menadžmenta znanja kao i zbog pretpostavke da imaju najveća finansijska sredstva i ljudske resurse da sprovedu takav vid inovacije. Male organizacije, prema autorima, takođe, imaju želju da usvoje koncept menadžmenta znanja, ali se suočavaju sa manjkom resursa veštine kod zaposlenih kao i finansijskim ograničenjima. $\mathrm{Na}$ osnovu rezultata studije, zaključak autora je da je veliki broj građevinskih kompanija svestan pogodnosti koje donosi menadžment znanja. Međutim, kompanije se suočavaju sa barijerama za implementaciju koncepta kao što su: nedostatak novca, slaba IT infrastruktura, organizaciona kultura i vremensko ograničenje.

A. Javernick-Will (2012) ispitivala je razloge za razmenu znanja zaposlenih $u$ građevinskim i kompanijama i firmama koje se bave nekretninama u SAD. U kvalitativnoj studiji slučaja, sprovedenoj na uzorku od 48 zaposlenih u 13 kompanija, autorka je utvrdila četiri glavna faktora koja utiču na razmenu znanja i percepciju vrednosti organizacijskog znanja: resursi, unutrašnja motivacija, globalni podsticaji, i socijalna motivacija. Ogromna većina ispitanih, kao razloge za motivaciju za razmenu znanja navodi socijalnu motivaciju, reciprocitet, usklađenost sa korporativnom kulturom, oponašanje lidera, svest o važnosti razmene znanja i informacija sa kolegama, poštovanje obaveze razmene znanja, i percepciju vrednosti organizacijskog znanja. Takođe, navode se strategije koje mogu da pomognu zaposlenima da povećaju razmenu znanja u kompanijama, uz određene nedostatke primene kvalitativnog metoda $u$ ovoj oblasti. Navodi se da u budućim istraživanjima treba povećati uzorak i koristiti kvantitativne metode sa standardnim upitnikom. Na taj način bi se izmerio rang značaja koji respondenti pridaju motivacionim faktorima otkrivenih $\mathrm{u}$ istraživanju. Povećanje uzorka bi omogućilo i uporedno istraživanje sa evropskim kompanijama u kojima se neguju drugačiji poslovni obrasci ponašanja. Prema S. Asad-u, M. Khalfan-u i P. McDermott (2005), primena menadžmenta znanja u građevinskom sektoru dovodi do unapređenja procesa i proizvoda usled razmene znanja u lancu snabdevanja, do uštede novca usled centralizacije komunikacije između poslovnih partnera ili povećanja zarade kao rezultata korišćenja centralizovanog znanja, kao izvora konkurentne prednosti za sklapanje novih i zadržavanje starih poslova. Građevinska industrija se suočava sa niskom produktivnošću, za šta R. Grover i T. Froese (2016) razlog vide $u$ oskudnom menadžmentu znanja. Pomenuti autori su primetili da se greške napravljene $\mathrm{u}$ jednom građevinskom projektu ponavljaju $\mathrm{u}$ budućim građevinskim poduhvatima. Glavni cilj $\mathrm{u}$ njihovom istraživanju bio je da procene korisnost socijalnih platformi za upravljanje implicitnim znanjem u građevinskoj industriji. Analiza primene socijalnih platformi u građevinskoj industriji obavljena na studiji slučaja firme AYO Smart Home iz Vankuvera, u vreme kada u Kanadi raste potražnja za jeftinim, trajnim i energetski efikasnim prostorom za stanovanje. Socijalne platforme koriste aplikacije za olakšavanje komunikacije i saradnje između različitih projektnih stakeholders-a. Prema procenama autora, korišćenjem aplikacije treba da se omogući učestvovanje dva ili više pojedinca $u$ kreativnom procesu, razmena kolektivnih veština, ekspertiza, bolje razumevanje informacija, a sve u poslovnoj atmosferi otvorenosti i uzajamnog poštovanja.

\section{EMPIRIJSKO ISTRAŽIVANJE}

\section{Uzorak i dizajn baze podataka}

U uzorak su uključene kompanije iz Beograda, Novog Sada i Niša, kao najvećih privrednih centara u RS. Osnovni uzorak je obuhvatio pet privrednih sektora: industrijski, građevinski, IT, trgovinski, i uslužni. Prilikom planiranja uzorka, vodilo se računa da udeo privrednih sektora u BDP-u RS bude verodostojno zadržan u uzorku (Republički zavod za statistiku, 2018). Prilikom odabira kompanija, obraćena je pažnja da u uzorku bude sačuvan realan odnos u broju mikro, malih, srednjih i velikih kompanija u RS. Za definisanje veličine kompanije, korišćeni su kriterijumi iz Zakona o računovodstvu (Vlada Republike Srbije, 2013). Izbor kompanija u uzorak obavljen je sa liste poslovnog direktorijuma 
RS (Stojanovic, 2018), korišćenjem metode prostog slučajnog uzorka bez ponavljanja. Za sakupljanje podataka korišćen je online upitnik sa zatvorenim odgovorima intervalskim i Likertovim lestvicama. Ispitivani su menadžeri izabranih kompanija. Intervju je sproveden od 1. novembra do 15. decembra 2018. Upitnik je distribuiran u tri talasa, u razmaku od petnaest dana. U drugom i trećem talasu ponovo su poslati upitnici kompanijama koje nisu dostavile odgovore posle prvog i drugog pokušaja. Od poslatih 360 upitnika, dobijeni su odgovori od 130 kompanija, koje predstavljaju osnovni uzorak. U Tabeli 2 prikazan je broj preduzeća po veličini i sektorima.

Tabela 2 Broj preduzeća po veličini i privrednim sektorima

\begin{tabular}{|c|c|c|c|c|c|}
\hline \multirow{2}{*}{$\begin{array}{l}\text { Privredni } \\
\text { sektor }\end{array}$} & \multicolumn{4}{|c|}{ Veličina preduzeća } & \multirow{2}{*}{ Ukupno } \\
\hline & Mikro & Mala & Srednja & Velika & \\
\hline Industrija & 4 & 9 & 10 & 8 & 31 \\
\hline $\begin{array}{l}\text { Građevina- } \\
\text { rstvo }\end{array}$ & 8 & 10 & 7 & 5 & 30 \\
\hline IT sektor & 7 & 8 & 2 & 3 & 20 \\
\hline Trgovina & 6 & 7 & 5 & 3 & 21 \\
\hline Usluge & 6 & 13 & 4 & 5 & 28 \\
\hline Ukupno & 31 & 47 & 28 & 24 & 130 \\
\hline
\end{tabular}

Izvor: Autori

U analizi se koristi i takozvani segmentirani uzorak, koji uključuje ukupno dvanaest srednjih i velikih građevinskih kompanija, ekstrahovanih iz osnovnog uzorka.

Za potrebe istraživanja, kreirana je baza podataka za merenje menadžmenta znanja u kompanijama. Baza podataka se sastoji od jedanaest varijabli svrstanih u pet tematskih celina. Prva celina, akademsko obrazovanje, uključuje tri varijable: udeo zaposlenih u kompaniji sa fakultetskim, master i doktorskim diplomama. Druga celina, pod nazivom obuka zaposlenih, podrazumeva sledeće varijable: pohađanje seminara i kurseva izvan kompanije, kao i pohađanje edukativnih seminara i kurseva $\mathrm{u}$ kompaniji. Treća tematska celina, skladištenje, sastoji se od sledećih varijabli: prisutnost organizovane procedure skladištenja potrebnog znanja korisnog za funkcionisanje firme i postojanje sistema zaštite i registracije inovativnih rešenja i procedura $u$ Zavodu za intelektualnu svojinu. Četvrta celina, diseminacija, sadrži dve varijable: postojanje obaveze učesnika inovativnih seminara znanja da izveštavaju odeljenja, sektore ili neposredne kolege o rezultatima, kao i varijablu koja meri postojanje obaveze da po povratku sa službenog puta (posle poseta sajmovima, izložbama i drugim poslovnim događajima), zaposleni imaju obavezu da obaveste saradnike o rezultatima koji se tiču delatnosti firme. Peta celina, pod nazivom, tehnička podrška, obuhvatila je dve varijable. Prva varijabla procenjuje mogućnost pristupa intranetu u kompanijama, dok druga meri mogućnost pristupa virtuelnim bibliotekama i bazama znanja. Varijable su merene pomoću intervalskih i četvorostepenih Likertovih lestvica, gde podeok 1 predstavlja minimalnu, a podeok 4 predstavlja maksimalnu vrednost merenog indikatora.

\section{Model, analiza i rezultati}

Jedanaest varijabli iz baze podataka za merenje menadžmenta znanja, obrađeno je tehnikom faktorske analize, na nivou osnovnog uzorka koji uključuje svih pet sektora $(n=130)$. Početna ideja je da se izoluje izvestan broj složenih faktora koji bi se posle doveli $u$ vezu sa poslovnim varijablama kompanije. Polazi se od sledećeg osnovnog modela:

$$
X_{i}=a_{i 1} F_{1}+a_{i 2} F_{2}+a_{i 3} F_{3}+a_{i 4} F_{4}+e_{i}
$$

gde je $X$ vrednost faktorskog skora, $i$ redni broj varijable, $F$ oznaka za faktore, a faktorsko punjenje, i $e$ specifični faktor vezan samo za datu varijablu.

U istraživanju je korišćena faktorska analiza sa metodom ekstrakcije maximum likelihood (Millar, 2011). Algoritam ekstrakcije u varijanti maximum likelihood (Field, 2005) je postavljen tako da je 
maksimalna verovatnoća opcija $\Lambda$ i $\psi 2$ dobijena minimizovanjem izraza 2:

$$
F=\operatorname{tr}\left[\left(\Lambda \Lambda^{\prime}+\psi 2\right)-1 R\right]-\log \left|\left(\Lambda \Lambda^{\prime}+\psi 2\right)-1 R\right|-p
$$

$\mathrm{i}$ to prema $\Lambda$ i $\psi 2$ respektivno, gde $p$ predstavlja broj varijabli, $\Lambda$ faktorsko punjenje matriksa, a $\psi 2$ dijagonalni matriks jedinstvene varijanse.

Minimizovanje $F$ se vrši preko dvostepenog logaritma. U prvom koraku se izračunava uslovni minimum za $F$, za dato $y$. Na taj način se dobija funkcija $f(\psi)$ koja je numerički minimizovana pomoću Njutn-Rapsonovog metoda (Field, 2005; Ahmad, Naing \& Hussein, 2007). Pošto su se stekli svi neophodni uslovi Kaiser-Mayerovog i Bartlett's-ovog testa za nastavak analize (Field, 2005), započeta je procedura faktorske analize. Posle varimax rotacije, izdvojena su četiri značajna složena faktora. Faktori sa punjenjima su prikazani u Tabeli 3. Posmatrano kumulativno, četiri faktora objašnjavaju
50\% ukupne varijanse. Generalno, minimalna vrednost faktorskih punjenja, koja se uzima u obzir $\mathrm{u}$ istraživanjima, je $\pm 0,3$ dok se faktorska opterećenja sa vrednostima $\pm 0,70$ smatraju indikativnim za jednu dobro definisanu strukturu i ona su pravi cilj faktorske analize (Hair, Black, Babin \& Anderson, 2010). U skladu sa tim, sve ćelije sa značajnim faktorskim punjenjima u Tabeli 3 su obojene u sivo.

Na nivou osnovnog uzorka, ekstrahovana su četiri faktora koja predstavljaju strategije koje kompanije koriste i kombinuju u menadžmentu znanja. Faktor 1 uključuje strategiju koja se oslanja na pohađanje edukativnih seminara unutar i izvan firme, obavezu izveštavanja odeljenja, sektora ili neposrednih kolega o rezultatima inovativnih seminara znanja, plaćanje pretplate za pristup virtuelnim bibliotekama i bazama znanja i organizovanje procedure skladištenja znanja korisnog za funkcionisanje firme. Na kraju, u okviru ove strategije, kompanije nastoje

Tabela 3 Rotirani faktorski matriks ${ }^{\mathrm{a}} \mathrm{n}=130$

\begin{tabular}{|c|c|c|c|c|}
\hline & \multicolumn{4}{|c|}{ Faktor } \\
\hline & 1 & 2 & 3 & 4 \\
\hline Broj zaposlenih sa fakultetskim diplomama \% & .308 & .053 & .460 & .125 \\
\hline Broj zaposlenih sa MSc/MA\% & .055 & .064 & .826 & -.021 \\
\hline Broj doktora nauka & .120 & -.019 & .207 & .430 \\
\hline Pohađanje seminara i kurseva izvan kompanije \% & .544 & .091 & .086 & .124 \\
\hline Pohađanje seminara i kurseva unutar kompanije \% & .948 & .046 & .208 & .078 \\
\hline $\begin{array}{l}\text { Da li postoje organizovane procedure skladištenja potrebnog znanja } \\
\text { korisnog za funkcionisanje firme? }\end{array}$ & .388 & .332 & .191 & .106 \\
\hline $\begin{array}{l}\text { Da li postoji sistem zaštite i registracije inovativnih rešenja i procedura u } \\
\text { Zavodu za intelektualnu svojinu? }\end{array}$ & .159 & .047 & -.119 & .798 \\
\hline $\begin{array}{l}\text { Da li postoji obaveza učesnika inovativnih seminara znanja da izveštavaju } \\
\text { odeljenja, sektore ili neposredne kolege o rezultatima? }\end{array}$ & .486 & .370 & -.070 & .216 \\
\hline $\begin{array}{l}\text { Da li po povratku sa službenog puta (posle poseta sajmovima, izložbama } \\
\text { i drugim poslovnim dogadjajima) zaposleni imaju obavezu da obaveste } \\
\text { saradnike o rezultatima koji se tiču delatnosti firme? }\end{array}$ & .168 & .969 & .070 & -.164 \\
\hline Da li postoji pristup virtuelnim bibliotekama i bazama znanja? & .575 & .155 & .097 & .132 \\
\hline Da li ste povezani preko intraneta? & .067 & .218 & .024 & .178 \\
\hline
\end{tabular}

Metod ekstrakcije: Maximum Likelihood. Rotacioni medot: Varimax sa Kaiser Normalizacijom.

a.Rotacija konvergirala u 5 iteracija

Izvor: Autori 
da među zaposlenima imaju što veći udeo fakultetski obrazovanih stručnjaka. Faktor 2 sadrži strategiju koja uključuje obavezu zaposlenih da po povratku sa službenog puta obaveste saradnike o rezultatima koji se tiču delatnosti firme, obavezu izveštavanja odeljenja, sektora ili neposrednih kolega o rezultatima inovativnih seminara znanja i procedure skladištenja znanja korisnog za funkcionisanje firme. U okviru Faktora 3, menadžment znanja se oslanja na strategiju u kojoj se nastoji da se među zaposlenima ima što veći procentualni udeo stručnjaka sa master i fakultetskim diplomama. Faktor 4 podrazumeva strategiju u okviru koje se stavlja akcenat na postojanje sistema formalnopravne zaštite i registracije inovativnih rešenja i procedura u odgovarajućim institucijama, kao i na što većem broju zaposlenih eksperata sa diplomom doktora nauka. Menadžment firme može da koristi jednu, ili da kombinuje više strategija za upravljanje znanjem. Odabir strategija zavisi od privrednog sektora, veličine firme, poslovnog okruženja i drugih okolnosti.

Pomoću dobijena četiri faktorska skora, moguće je meriti uticaj strategija menadžmenta znanja na poslovne varijable kompanije. U istraživanju je meren uticaj faktorskih skorova na poslovnu varijablu zarada. Zarada zaposlenih u kompanijama merena je preko lestvice sa tri numerička stepena. U anketi je korišćeno sledeće pitanje: Da li je prosečna zarada u vašoj firmi manja, ista ili veća od republičkog proseka za RS? Analiziran je uticaj četiri faktorska skora na zarade u srednjim i velikim građevinskim kompanijama. Testirana je operacionalna hipoteza H1: Regresioni faktorski skorovi 1-4 (kao nezavisne varijable, prediktori) utiču na promenu zavisne varijable - prosečna zarada zaposlenih u kompaniji u srednjim i velikim građevinskim kompanijama. Da bi se testirala hipoteza, obavljena je segmentacija osnovnog uzorka, iz koga je izdvojeno ukupno dvanaest srednjih i velikih građevinskih kompanija. Posle obavljene segmentacije, postavljen je sledeći višestruki regresioni model:

$$
w_{i}=\beta_{0}+\beta_{2} f i_{1}+\beta_{2} f i_{2}+\beta_{3} f i_{3}+\beta_{4} f i_{4}+\varepsilon_{i}
$$

Gde je, za $i=n$, observacija:

$w_{i}=$ zavisna varijabla (prosečna zarada u kompaniji)

$\beta_{0}=w$ intercept (constant)

$\beta_{1}=$ nagib koeficijenta prediktora $f_{i 1}$

$\beta_{2}=$ nagib koeficijenta prediktora $f_{i 2}$

$\beta_{3}=$ nagib koeficijenta prediktora $f_{i 3}$

$\beta_{4}=$ nagib koeficijenta prediktora $f_{i 4}$

$f_{i 1^{\prime}} f_{i 2^{\prime}} f_{i 3^{\prime}} f_{i 4}=$ nezavisne varijable ili prediktori (regresioni faktorski skor-ovi 1 - 4)

$\varepsilon_{i}=$ slučajna greška

Rezultati pokazuju značajne vrednosti za sva tri koeficijenta R (Tabela 4). Zbog ograničenja manjeg uzorka, $\mathrm{u}$ analizi se koristi korigovani koeficijent determinacije $\mathrm{R}^{2}$ koji ima strožije kriterijume. Na osnovu vrednosti korigovanog $\mathrm{R}^{2}$, set od četiri prediktorske varijable objašnjava $84,5 \%$ varijabilnosti prosečne zarade zaposlenih u kompaniji.

Tabela 4 Srednje i velike građevinske kompanije: Regresiona analiza Sumiranje modela

\begin{tabular}{ccccc}
\hline Model & $\mathrm{R}$ & $\mathrm{R}^{2}$ & $\begin{array}{c}\text { Korigovani } \\
\mathrm{R}^{2}\end{array}$ & $\begin{array}{c}\text { Std. greška } \\
\text { procene }\end{array}$ \\
\hline 1 & $.949 \mathrm{a}$ & .901 & .845 & .153 \\
\hline
\end{tabular}

a. Prediktori: (Constant), REGR faktorski skor 4 za analizu 1, REGR faktorski skor 2 za analizu 1, REGR faktorski skor 1 za analizu 1, REGR faktoski skor 3 za analizu 1

Izvor: Autori

U Tabeli 5, vide se doprinosi po faktorskim skorovima. Statistički značajan uticaj na prosečne zarade zaposlenih imaju faktorski skorovi 3 i 4 . Prema tome, menadžment građevinskih kompanija koristi kombinaciju dve strategije za upravljanje znanjem. Prva strategija uključuje nastojanja menadžmenta da među zaposlenima ima što veći procentualni udeo stručnjaka sa master i fakultetskim diplomama, jer $\mathrm{u}$ 
njima uprava vidi izvore inovativnih rešenja korisnih za kompaniju.

Tabela 5 Srednje i velike građevinske kompanije: Koeficijentia

\begin{tabular}{|c|c|c|c|c|c|}
\hline Model & $\begin{array}{c}\text { Nest } \\
\text { rdiz } \\
\text { koef } \\
\text { B }\end{array}$ & $\begin{array}{l}\text { tanda- } \\
\text { ovani } \\
\text { icijenti } \\
\text { Std. } \\
\text { greška }\end{array}$ & $\begin{array}{c}\begin{array}{c}\text { Standard- } \\
\text { izovani } \\
\text { koeficijenti }\end{array} \\
\text { Beta }\end{array}$ & $t$ & Sig. \\
\hline (Constant) & 2.281 & .099 & & 23.067 & .000 \\
\hline $\begin{array}{l}\text { REGR. faktorski } \\
\text { skor } 1 \text { za analizu } \\
1\end{array}$ & -.040 & .119 & -.083 & -.336 & .747 \\
\hline $\begin{array}{l}\text { REGR. faktorski } \\
1 \text { skor } 2 \text { za } \\
\text { analizu } 1\end{array}$ & .037 & .091 & .055 & .406 & .697 \\
\hline $\begin{array}{l}\text { REGR. faktorski } \\
\text { skor } 3 \text { za } \\
\text { analizu } 1\end{array}$ & .731 & .166 & 1.209 & 4.400 & .003 \\
\hline $\begin{array}{l}\text { REGR. faktorski } \\
\text { skor } 4 \text { za } \\
\text { analizu } 1\end{array}$ & .302 & .108 & .451 & 2.797 & .027 \\
\hline
\end{tabular}

a. Zavisna varijabla: Da li je prosečna zarada u Vašoj kompaniji manja, jednaka ili veća od republičkog proseka?

Izvor: Autori

Druga strategija se odnosi na uvođenje formalnopravne zaštite i registraciju inovativnih rešenja i procedura u Zavodu za intelektualnu svojinu, kao i na insistiranje na većem broju zaposlenih doktora nauka. Imajući u vidu vrednosti koeficijenta $\beta$, prva strategija pojedinačno dovodi do većeg porasta prosečnih zarada u kompaniji. Kada faktorski skor 3 skoči za jedan podeok, zarade zaposlenih se uvećaju za 0,731. U slučaju da faktorski skor 4 poraste za jedan podeok, zarade skaču za 0,302. Konstatujemo da je hipoteza H1 potvrđena. Segmentacija i diferencijacija gledano po srednjim, odnosno, velikim kompanijama posebno, nije bila moguća, jer se u tom slučaju veličina uzorka smanjuje ispod granice statističke prihvatljivosti.

\section{ZAKLJUČAK}

$\mathrm{U}$ radu je analiziran uticaj menadžmenta znanja na rast zarada $u$ srednjim $i$ velikim građevinskim kompanijama u Republici Srbiji. Za potrebe istraživanja, kreirana je baza podataka za merenje menadžmenta znanja koja je sastavljena od jedanaest varijabli. Posle faktorske analize, identifikovane su strategije koje se primenjuju u menadžmentu znanja. Zatim je analiziran uticaj regresionih faktorskih skorova na promenu zavisne varijable prosečna zarada u srednjim i velikim građevinskim kompanijama. $\mathrm{Na}$ osnovu dobijene vrednosti korigovanog koeficijenta determinacije $\mathrm{R}^{2}$, utvrđeno je da regresioni faktorski skorovi objašnjavaju $84,5 \%$ varijabilnosti prosečne zarade zaposlenih u kompaniji, čime je potvrđena hipoteza rada.

Menadžment građevinskih kompanija kombinuje dve statistički značajne strategije za upravljanje znanjem. U prvoj strategiji, menadžment teži da među zaposlenima ima što veći broj radnika sa master i fakultetskim diplomama, videći u njima potencijalni izvor za inovacije u kompaniji. Druga strategija uključuje implementaciju pravne zaštite i registracije kompanijskih inovativnih rešenja i procedura $u$ Zavodu za intelektualnu svojinu, kao i nastojanja da se zaposli veći broj doktora nauka. Kada se regresioni faktorski skor 3, koji se odnosi na prvu strategiju, uveća za jedan podeok, zarade zaposlenih se povećaju za 0,731. Kada faktorski skor 4, koji se odnosi na drugu strategiju, poraste za jedan podeok, zarade $\mathrm{u}$ građevinskim kompanijama se povećaju za 0,302. Kada se govori o uzorku, mogu se primetiti određena ograničenja, koja se odnose na mali broj kompanija u segmentiranom uzorku. Međutim, na osnovu uvida $\mathrm{u}$ jasan trend dobijenih odgovora, veruje se da veći uzorak ne bi uticao na promenu rezultata.

P. Romer (Brueck, 2018) naglašava značaj uticaja endogene akumulacije znanja za povećanje prinosa. On ističe, da umesto da iznova ponavljaju iste pokrete, naporno radeći u fabrikama ili na računarima, ljudi kroz akumulaciju znanja mogu da preurede svet i otkriju nove ideje. Na tržištu ideja, postoji efekat grudve snega. Kako tvrdi P. Romer "Što više znamo, lakše otkrivamo". 
Implikacije rezulata istraživanja se, pre svega, odnose na orijentaciju ka unutrašnjem tržištu u kompanijama. Pojam unutrašnjeg tržišta podrazumeva da menadžerska i vlasnička struktura u zaposlenima vidi potrošače njihovih proizvoda, među kojima su zarade i stimulansi najvažniji, potom, hijerarhijske pozicije, treninzi i ostalo. Kako je broj ovih internih proizvoda ograničen, ostaje prevashodni značaj zarada koje pružaju mogućnost za gradualistički pristup u odnosu na iskazano znanje i doprinos. Iz tog razloga, upravljanje znanjem na segmentiranom unutrašnjem tržištu, kako to i rezultati istraživanja pokazuju, proizvodi značajne implikacije za kompanijske rezultate.

\section{REFERENCE}

Ahmad, W., Naing, N., \& Hussein, M. (2007). Selection for parameter $\Lambda$ by using newton-raphson method. Statistika, 7(2), 33-37. Retrieved July 25, 2019 from https://ejournal. unisba.ac.id/index.php/statistika/article/download/987/582

Asad, S., Khalfan, M., \& McDermott, P. (2005, April). Managing knowledge across the construction supply Chain. Paper presented at SCRI Symposium in Salford, UK, 12 -13 April, Retrieved July 20, 2019 from https://www.irbnet.de/daten/ iconda/CIB16777.pdf 20/07/2019

Brueck, H. (2018). Economist Paul Romer just won the Nobel Prize in economics-and his ideas sound like the backbone of Bill Gates' philanthropy playbook. Business Insider (Oct. 8th), Retrieved July 26, 2019 from https://www.businessinsider. com/paul-romer-nobel-prize-in-economics-endogenousgrowth-theory-2018-10

Dang, G., \& Sui Pheng, L. (2015). Infrastructure Investments in Developing Economies: The Case of Vietnam. Singapore: Springer

Davenport, T. H. (1994). Saving IT's Soul: Human Centered Information Management. Harvard Business Review, 72(2), 119-131.

Deutsch, A. (2019). The 5 Industries Driving the U.S Economy. Retrieved July 20, 2019, from https://www.investopedia. com/articles/investing/042915/5-industries-driving-useconomy.asp

Drucker, P. F. (1993). Managing in Turbulent Times. London, UK: Routledge.
Durduyev, S., \& Ismail, S. (2012). Role of the Construction industry in economic development of Turkmenistan. Energy Education Science and Technology Part A: Energy Science and Research, 29(2), 883-890.

Field, A. P. (2005). Discovering statistics using SPSS. London, UK: Sage.

Forcada, N., Casals, M., Roca, X., \& Gngolells, M. (2006, January). Knowledge management in the construction sector: A case study. Paper presented at CIB W107 Construction in Developing Countries International Symposium Construction in Developing Economies: New Issues and Challenges 18-20 January 2006, Santiago, Chile. Retrieved July 18, 2019, from http://www.irbnet.de/daten/iconda/ CIB1921.pdf

Girard, J., \& Girard, J. (2015). Defining knowledge management: Toward an applied compendium. Online Journal of Applied Knowledge Management, 3(1), 1-20.

Grover, R., \& Froese, T. (2016). Knowledge management in construction using a SocioBIM platform: A case study of AYO smart home project. Procedia Engineering, 145, 12831290. doi.org/10.1016/j.proeng.2016.04.165

Hair, J., Black, W., Babin, B., \& Anderson, R. (2010). Multivariate Data Analysis - A Global Perspective. New Jersey, NJ: Pearson Education.

Hartman, D. (2017). Importance of wages. Bizfluent portal. Retrieved July 21, 2019, from https://bizfluent.com/info8228392-importance-wages.html

Javernick-Will, A. (2012). Motivating knowledge sharing in engineering and construction organizations: Power of social motivations. Journal of Managemen in Engineering, 28(2), 193-202. doi:10.1061/(ASCE)ME.1943-5479.0000076

Khan, R. (2008, August). Role of construction sector in economic growth: Empirical evidence from Pakistan economy. Paper presented at First International Conference on Construction In Developing Countries (ICCIDC-I)"Advancing and Integrating Construction Education, Research \& Practice", August 4-5, 2008, Karachi, Pakistan.

Leal, C., Cuhna, S., \& Cuoto. I. (2017). Knowledge sharing in construction sector-faciliators and inhibitors. Procedia Computer Science 121, 998-1005. doi.org/10.1016/j. procs.2017.11.129

Mallick, H., \& Mahalik, M. (2010). Constructing the economy: The role of construction sector in India's growth. Journal of Real Estate Finance and Economics, 40(3), 368-384. doi:10.1007/ s11146-008-9137-z 
Millar, R. B. (2011). Maximum Likelihood Estimation and Inference: With Examples in R, SAS and ADMB. New York, NY: John Wiley and Sons.

Mladenovic, I. (2013). The Construction industry in function of the recovery of the Republic of Serbia economy. Economic horizons 15(3), 249-259. doi:10.5937/ekonhor1303245M

Narodna Banka Srbije. (2019). Makroekonomska kretanja u Srbiji (Jul). Preuzeto 26. jula 2019. sa https://www.nbs.rs/internet/ latinica/18/18_3/prezentacija_invest.pdf

Nonaka, I. (1991). The knowledge-creating company. Harvard Business Review, 69(6), 96-104.

Park, J., Ham, T., \& Hong, T. (2012). Construction Business cycle analysis using the regime switching model. Journal of Management in Engineering, 28(4), 362-371. doi:10.1061/ (ASCE)ME.1943-5479.0000107

Republički zavod za statistiku. (2018). Bruto domaći proizvod 2017. Preuzeto 25.oktobra 2019. sa https://www.stat.gov.rs/ sr-latn/vesti/20181001-bruto-doma\%C4\%87i-proizvod-2017/

Robinson, H., Carrillo, P., Anumba, C., \& Al-Ghassani, M. (2001, September). Perceptions and Barriers in Implementing Knowledge Management Strategies in Large Construction Organizations. Proceedings of the RICS Foundation Construction and Building Research Conference, 3-5 Sept. Volume 2 (p. 451460). Glasgow, UK: Glasgow Caledonian University.

Rouse, M. (2013). Knowledge Management(KM). SearchDomino websait. Retrieved July 14, 2019, from https://searchdomino. techtarget.com/definition/knowledge-management

Ruddock, L., \& Lopes, J. (2006). The construction sector and economic development: The 'Bon curve'. Construction Management and Economics, 24(7), 717-723. doi:10.1080/01446190500435218
Službeni glasnik. (2018). Prosečne zarade po zaposlenom u RS. Službeni glasnik RS 7/2018.

Stojanovic, G. (2018). Serbian Business Directory. Beograd, RS: TELCOM.

Stanišić, N. (2017). Makroekonomske koristi od unapređenja energetske efikasnosti u stambenim zgradama u Srbiji. Bonn/ Eschborn: Deutsche Gesellschaft für Internationale Zusammenarbeit (GIZ) GmbH

Tebaldi, E. (2014). The Economic Impact of the Construction Industry on the Economy of Rhode Island in 2013. Smithfield, Rhode Island: Bryant University, Center for Global and Regional Economic Studies.

Vlada Republike Srbije. (2013). Zakon o računovodstvu. Službeni glasnik RS, 62/2013, 4-5.

Webster. (2010). Webster's New World Finance and Investment Dictionary. Indianapolis, Ind: Wiley Publishing, Inc.

Wibowo, A., Sugiyanto, F. X., Firmansyah, M., \& Amoudi, O. (2008, November). The effects of the Indonesian construction industry on the economy: A series of inputoutput table analysis. Proceedings of CIB W055 - W065 Joint International Symposium, 15-18 Nov. Heriot-Watt University, School of the Built Environment, UK. Retrieved July 19, 2019, from http://www.irbnet.de/daten/iconda/CIB17549. pdf

Wisniewska-Salek, A. (2019). Knowledge management Education in the light of Industry 4.0. CzOTO, 1(1), 969-977. doi.org/10.2478/czto-2019-0123

Xu, M., David, J., \& Kim, S. (2018). The fourth industrial revolution: Opportunities and challenges. International Journal of Financial Research, 9(2), 90-95. doi:10.5430/ijfr. v9n2p90

Primljeno 3. decembra 2019, nakon revizije, prihvaćeno za publikovanje 13. aprila 2020. Elektronska verzija objavljena 24. aprila 2020. 
Vojislav Babić je istraživač na Institutu za sociološka istraživanja Filozofskog fakulteta, Univerziteta u Beogradu. Doktorirao je na Ekonomskom fakultetu Univerziteta u Beogradu. Usavršava se na Univerzitetu Ca' Foscari u Veneciji, na Departmanu za ekonomiju. Oblasti njegovog istraživačkog interesovanja su preduzetništvo, institucionalna ekonomija, i ekonomska statistika.

Siniša Zarić je redovni profesor Ekonomskog fakulteta Univerziteta u Beogradu, gde je i doktorirao. Ključne oblasti njegovog naučnoistraživačkog interesovanja su metod ekonomske analize i institucionalna ekonomija.

\title{
THE IMPACT OF KNOWLEDGE MANAGEMENT ON WAGE GROWTH IN THE CONSTRUCTION SECTOR: THE CASE OF MEDIUM-SIZED AND LARGE COMPANIES IN THE REPUBLIC OF SERBIA
}

\author{
Vojislav Babic ${ }^{1}$ and Sinisa Zaric ${ }^{2}$ \\ ${ }^{1}$ Institute for Sociological Research, Faculty of Philosophy, University of Belgrade \\ ${ }^{2}$ Faculty of Economics, University of Belgrade
}

The study measures and analyzes the influence of knowledge management on average wages in Serbian construction companies. For the purpose of this research, a KM dataset with 11 variables was created. The main goal of the research was to examine the influence of the dataset on the average wages in medium-sized and large construction companies. At the basic sample level, through factor analysis, a total of four factor scores were isolated, representing the strategies that the companies combine in KM. Using a regression analysis, it was found that the set of the four independent variables explained $84.5 \%$ of the average wage variability in the medium-sized and large construction companies. Two of the four strategies were statistically significant. According to the first strategy, the management insisted on a larger share of experts with the master's and bachelor degrees, while the second strategy was based on the introduction of the formal, legal protection and registration of innovative solutions, as well as a larger number of employees with a PhD degree.

Keywords: knowledge management, construction sector, factor analysis, multiple regression, wages, midsize and large companies

JEL Classification: M21, M150 